\title{
Scinax cruentommus (Anura: Hylidae) in the upper Rio Negro drainage, Amazonas state, Brazil, with the redescription of its advertisement call
}

\author{
Thiago R. de Carvalho ${ }^{1,2}$, Bernardo F. V. Teixeira ${ }^{1,2}$, William E. Duellman ${ }^{3}$, and Ariovaldo A. \\ Giaretta ${ }^{1}$ \\ ${ }^{1}$ Laboratório de Taxonomia, Sistemática e Ecologia Comportamental de Anuros Neotropicais, Faculdade de Ciências Integradas \\ do Pontal, Universidade Federal de Uberlândia (UFU), Rua 20, 1600, 38304-402, Ituiutaba, Minas Gerais, Brazil. E-mail: \\ thiago_decarvalho@yahoo.com.br. \\ ${ }^{2}$ Programa de Pós-Graduação em Biologia Comparada, Departamento de Biologia/FFCLRP, Universidade de São Paulo, \\ Avenida dos Bandeirantes, 3900, 14040-901, Ribeirão Preto, São Paulo, Brazil. \\ ${ }^{3}$ Biodiversity Institute, University of Kansas Lawrence, Kansas 66045-7561, USA.
}

\begin{abstract}
Scinax cruentommus (Anura: Hylidae) in the upper Rio Negro drainage, Amazonas state, Brazil, with the redescription of its advertisement call. We provide the first record for Scinax cruentommus from the upper Rio Negro, Amazonas state, Brazil. We also redescribe its advertisement call and make acoustic comparisons with available data for other species of the Scinax ruber Clade in the Amazon Basin. With the assessment of further data on $S$. cruentommus, the acoustic traits have supplemented its congeneric diagnosis in comparison with the other Amazonian species of the S. ruber Clade besides the features proposed in its original description.
\end{abstract}

Keywords: Bioacoustics, distribution patterns, Scinax ruber Clade, taxonomy.

\begin{abstract}
Resumo
Scinax cruentommus (Anura: Hylidae) na bacia do alto Rio Negro, Amazonas, Brasil, com a redescrição do seu canto de anúncio. Nós apresentamos o primeiro registro de Scinax cruentommus no alto Rio Negro, Amazonas, Brasil. Nós também redescrevemos o seu canto de anúncio e fazemos comparações acústicas com os dados disponíveis para outras espécies do Clado de Scinax ruber da bacia amazônica. Com a obtenção de novos dados para $S$. cruentommus, os parâmetros acústicos suplementaram a sua diagnose congenérica em relação às outras espécies amazônicas do Clado de $S$. ruber além das características propostas em sua descrição original.
\end{abstract}

Palavras-chave: Bioacústica, Clado de Scinax ruber, padrões de distribuição, taxonomia. 


\section{Introduction}

The genus Scinax currently consists of 113 species distributed in eastern and southern Mexico, central America, and throughout South America southward to northern Argentina and Uruguay (Frost 2015). Faivovich (2002) proposed two major clades for the genus based mainly on morphological evidence; these clades, the $S$. catharinae Clade and the $S$. ruber Clade, were corroborated by Faivovich et al. (2005) based on a larger taxon sampling and genetic evidence. Scinax cruentommus (Duellman 1972), a member of the $S$. ruber Clade, was described from Amazonian Ecuador, and has been reported for other Amazonian regions including localities in Brazil (França and Venâncio 2010; Bernarde et al. 2011).

Herein we report the first record of Scinax cruentommus from the upper Rio Negro, northwestern Amazonas state, northern Brazil, and redescribe its advertisement call. Additionally, we make acoustic comparisons with available data on species of the $S$. ruber Clade in the Amazon Basin.

The new distribution record of $S$. cruentommus in the Amazon Basin might contribute to a better understanding of the distribution patterns of Amazonian frogs, as well as the conservation status of species and priority areas for conservation in the Amazon Rainforest. The redescription of $S$. cruentommus advertisement call is particularly important with regard to a reappraisal of the acoustic data available for this species in the original description based on digital recordings and a larger sample size, besides the supplement of its specific diagnosis through the application of acoustic traits in comparison with congeneric species of the $S$. ruber Clade in the Amazon Basin.

\section{Materials and Methods}

Fieldwork was conducted by TRC and BFVT in June 2014 in the District of Cucuí ( $1^{\circ} 11^{\prime} 54.75^{\prime \prime}$ $\mathrm{N}, 66^{\circ} 50^{\prime} 18.93^{\prime \prime} \mathrm{W}$, ca. $80 \mathrm{~m}$ a.s.l.; WGS84 datum), Municipality of São Gabriel da Cachoeira, Amazonas State, northern Brazil. Collected specimens are housed in the Collection of Amphibians of the Museu de Biodiversidade do Cerrado at the Universidade Federal de Uberlândia (AAG-UFU) under the following accession numbers: AAG-UFU 3876-3881; AAG-UFU 3876-3878 are call voucher males. Morphological, morphometric, and coloration features follow the original description of $S$. cruentommus by Duellman (1972) and a revisionary paper on Scinax species in Amazonian Ecuador and Peru (Duellman and Wiens 1993). Snout-vent length (SVL) was measured with calipers to the nearest $0.05 \mathrm{~mm}$ according to Duellman (1970).

Calls of five males were recorded using a Sennheiser K6/ME67 directional microphone and a Marantz PMD 671 digital recorder, or a Sennheiser K6/ME66 directional microphone and a M-Audio Microtrack-II digital recorder, both set at a sampling rate of $48 \mathrm{kHz}$ and a resolution of 16 bits, and analyzed with Raven Pro 32-bit version 1.5 (Bioacoustics Research Program 2012). Temporal traits were measured from oscillograms; spectral traits (lower and higher bands of emphasized frequency) were obtained from spectrograms through the "Peak Frequency" measurement function. Raven Pro settings: window size $=256$ samples; window type $=$ Hann; $3 \mathrm{~dB}$ filter bandwidth $=270 \mathrm{~Hz}$; overlap $=85 \%$; hop size $=0.79 \mathrm{~ms}$; DFT size $=$ 1024 samples; grid spacing $=46.9 \mathrm{~Hz}$. Sound figures were generated with Seewave package version 1.7.3 (Sueur et al. 2008), R platform version 3.1.0 ( $\mathrm{R}$ Core Team 2014), with the following settings: window type = Hanning; window length $=256$ samples $($ FFT) ; overlap = 85\%. Acoustic definitions and terminology follow Duellman and Trueb (1994). Air and water temperatures were measured just after each recording (1 to 2 minute length recordings) with an Instrutherm digital thermometer (accurate to $0.1^{\circ} \mathrm{C}$ ).

Bilate and Lack (2011) summarized advertisement call traits for several species of the $S$. 
ruber Clade. These authors proposed a straightforward classification of calls based on their duration: short (up to approximately 350 $\mathrm{ms}$ ) and long (longer than $350 \mathrm{~ms}$ ) calls. We followed their classification to facilitate interspecific comparisons. Acoustic comparisons only included species of the $S$. ruber Clade in the Amazon Basin unassigned to any species group (all species but the $S$. rostratus and $S$. uruguayus groups; Faivovich et al. 2005).

\section{Results}

Our specimens (Figure 1) were identified as Scinax cruentommus by comparison with the original description (Duellman 1972) and another description of topotypical specimens (Duellman 1978). Thus, the Brazilian specimens are diagnosed as: (1) moderately small species (SVL
23.1-25.3 mm; $N=5$ adult males); (2) no webbing on hand; (3) toes about one-half webbed, but vestigial between first and second toes; (4) skin on dorsum smooth to finely shagreened; (5) dorsum tan usually with dark brown dorsal markings; (6) no bold vertical dark bars or mottling enclosing yellow spots on the posterior surfaces of thighs; (7) bright yellow vocal sac; (8) bronze iris with a median horizontal red streak; (9) \pm nuptial excrescences/ pads present in adult males $(N=3)$, but not evident in some specimens $(N=2)$; (10) advertisement call consisting of a single type of moderately long (call duration: 216-336 ms) and fast-pulsed (pulse rate/s: 153.8-192.8) note.

Males of Scinax cruentommus were observed calling perched from 0.5 to $1.0 \mathrm{~m}$ high on herbaceous vegetation at the margins of the river (Rio Negro), typical "Igapó" flooded forest
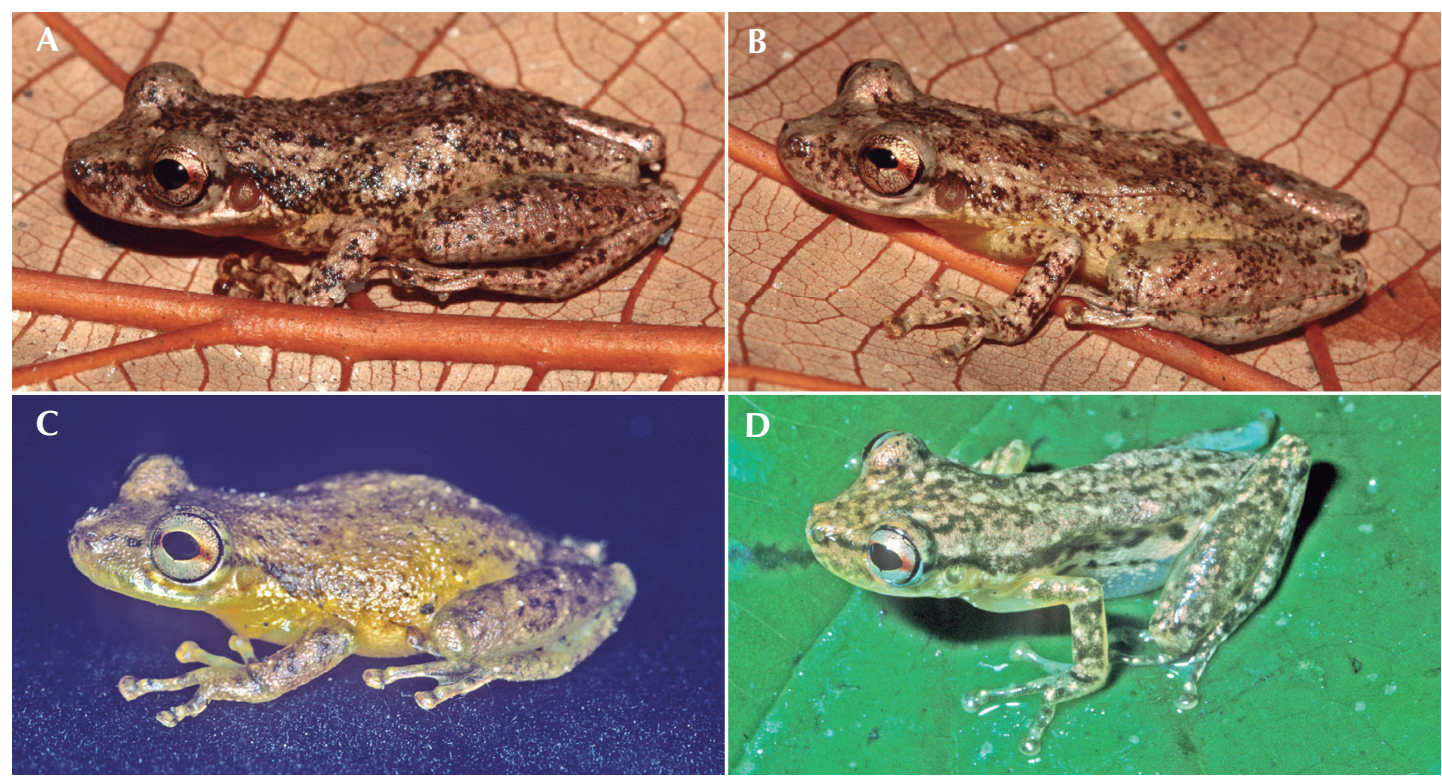

Figure 1. Adult males of Scinax cruentommus with the distinctive horizontal red streak on iris. (A) AAG-UFU 3876, SVL $23.4 \mathrm{~mm}$. (B) AAG-UFU 3877, SVL $25.3 \mathrm{~mm}$, both from Cucuí, upper Rio Negro, Amazonas state, Brazil; photographs by T. R. Carvalho. (C) KU 111924, 28.0 mm, from Santa Cecilia, Sucumbíos, Ecuador, photograph by J. D. Lynch. (D) KU 221959, 22.6 mm, from Teniente López, Loreto, Peru, photograph by W. E. Duellman. 
environments. Syntopic species were Dendropsophus tintinnabulum, Hypsiboas boans, $H$. cinerascens, Leptodactylus validus, Rhinella marina, Rhinella sp. (Rhinella margaritifera group), and Scinax ruber.

\section{Advertisement Call}

The call consists of a single type of pulsed signal with deep and regular amplitude modulations throughout its duration, with its final portion having a remarkably lower sound energy with ill-defined amplitude modulations (Table 1; Figure 2). Calls were commonly emitted in series or seldomly emitted as isolated notes ( $N=15$ out of 147 calls). Series were composed of $2-10$ calls $(\bar{X}=3.6 \pm 0.6)$; their duration varied from 0.9 to $8.5 \mathrm{~s}(\bar{X}=2.5 \pm 0.6)$. In the cases of series, calls were emitted at rates of $1.1-2.3$ calls per second $(\bar{X}=1.6 \pm 0.2)$. Call duration varied from 216 to $336 \mathrm{~ms}(\bar{X}=269.0 \pm$
22.1 ) with intervals of $325-1281 \mathrm{~ms}(\bar{X}=582.0$ \pm 127.6). Calls had $39-54$ pulses $(\bar{X}=46.9 \pm$ $2.6)$, emitted at rates of $153.8-192.8$ pulses per second $(\bar{X}=174.6 \pm 7.6)$. Two emphasized frequency bands were observed, the lower band almost always corresponded to the dominant frequency, varying from $2156-2438 \mathrm{~Hz}(\bar{X}=$ $2322.4 \pm 91.7$ ), but 9 of 37 calls of one male had the higher band coincident with the dominant frequency, which varied from $4406-4875 \mathrm{~Hz}$ $(\bar{X}=4654.3 \pm 156.6)$.

The advertisement call of Scinax cruentommus is categorized as a short call (call duration $<350 \mathrm{~ms}$ ) (sensu Bilate and Lack 2011). Compared to the calls of congeneric species of the $S$ ruber clade in the Amazon Basin, S. cruentommus can be distinguished from the species with long ( $\geq 350 \mathrm{~ms}$; Bilate and Lack 2011) calls [S. boesemani (Duellman 1986), S. exiguus (Duellman 1986), S. madeirae (Brusquetti et al. 2014), and S. wandae (Pyburn

Table 1. Advertisement call traits for Scinax cruentommus from Cucuí, Amazonas state, northern Brazil. Number of recorded males $=5$, number of analyzed calls $=147$.

\begin{tabular}{lcc}
\hline & Mean \pm SD & Range \\
\hline Call duration $(\mathrm{ms})$ & $269.0 \pm 22.1$ & $216-336$ \\
Call interval $(\mathrm{ms})$ & $582.0 \pm 127.6$ & $325-1281$ \\
Pulses/call & $46.9 \pm 2.6$ & $39-54$ \\
Pulse rate/s & $174.6 \pm 7.6$ & $2-192.8$ \\
Calls/series & $3.6 \pm 0.6$ & $0.9-8.5$ \\
Series duration $(\mathrm{s})$ & $2.5 \pm 0.6$ & $1.1-2.3$ \\
Call rate/s & $1.6 \pm 0.2$ & $2156-2438$ \\
Lower frequency band $(\mathrm{Hz})$ & $2322.4 \pm 91.7$ & $4406-4875$ \\
Higher frequency band $(\mathrm{Hz})$ & $4654.3 \pm 156.6$ & $26.5-28.5$ \\
Air temperature $\left({ }^{\circ} \mathrm{C}\right)$ & - & - \\
Water temperature $\left({ }^{\circ} \mathrm{C}\right)$ & 28.0 & 2.5 \\
\hline
\end{tabular}




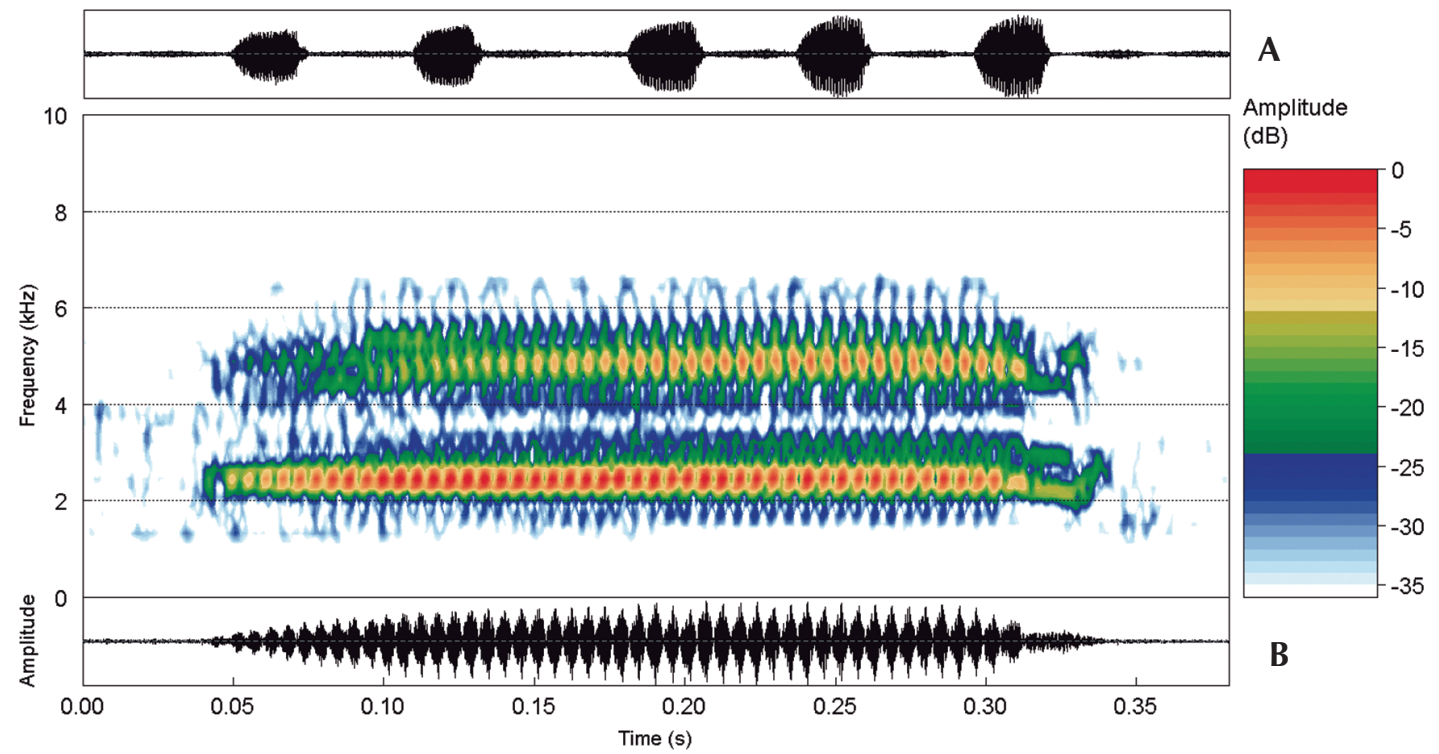

Figure 2. Advertisement call of Scinax cruentommus. (A) Waveform of a series of five calls (ca. 4.5 s); (B) spectrogram and respective oscillogram of the fourth call from A. Sound file: Scinax_cruentomCucuiAM1TRC_AAGm671; recorded at 00:10 h, on 29 June 2014 ; air $26.5^{\circ} \mathrm{C}$, water $28.0^{\circ} \mathrm{C}$. Recorded at Cucuí (São Gabriel da Cachoeira), Amazonas state, northern Brazil.

and Fouquette 1971)] by its shorter call duration (216-336 ms). Compared to species possessing short calls $(<350 \mathrm{~ms})$, S. cruentommus can be distinguished from S. blairi (18-22 pulses/call; Fouquette and Pyburn 1972) by a higher pulse number (39-54 pulses/call); from S. ictericus (70-90 ms; Duellman and Wiens 1993), $S$. lindsayi (80-100 ms; Pyburn 1992), S. oreites (80-110 ms; Duellman and Wiens 1993), and $S$. ruber (140-160 ms; Duellman and Pyles 1983) by a longer call duration (216-336 ms); from $S$. manriquei (at least two different types of notes; Barrio-Amorós et al. 2004) by having the advertisement call composed of a single type of note. The call of $S$. cruentommus cannot be entirely differentiated from those of $S$. chiquitanus and $S$. danae, species that are widely separated geographically from S. cruentommus (see Duellman 1986, Duellman and Wiens 1993).

\section{Distribution}

Scinax cruentommus is now known to have a broad distribution in the upper Amazon Basin (Figure 3). Our specimens of S. cruentommus from Cucuí (northwestern Amazonas) represent the first record of this species in the upper Rio Negro, northern Brazil. In addition to Ecuador (type locality, Duellman 1972), S. cruentommus was reported for other Amazonian regions: Peru (Duellman and Wiens 1993), Colombia (Lynch 2005; Malambo-L and Madrid-Ordóñez 2008), French Guyana (Lescure and Marty 2000), and northern Brazil (Amazonas: França and Venâncio 2010; Acre: Bernarde et al. 2011). Zimmerman and Rodrigues (1990) cited S. cruentommus for INPA-WWF reserves near Manaus. Subsequently, no other records of this species were reported for the region, including the municipality of Manaus and its outskirts, as well as the 
Reserva Florestal Adolpho Ducke, a forest reserve in the same region with a species list available as a field guide (Lima et al. 2005).

\section{Discussion}

We found differences in both temporal and spectral traits of the advertisement call of Scinax cruentommus in Amazonas, Brazil, and the description at Santa Cecilia, Provincia Sucum- bíos, Ecuador (Duellman 1972). In our sample, call duration was 216-336 ms; pulse rate was $153.8-192.8 / \mathrm{s}$, and dominant frequency more often was $2156-2438 \mathrm{~Hz}$, whereas these call traits were $350-370 \mathrm{~ms}, 160-170 / \mathrm{s}$, and 3200$3400 \mathrm{~Hz}$, respectively, in Duellman (1972). Still, the range of pulse rate in the original description was encompassed by our wider range. This might be due to the low sound input in the original recordings, hence hampering a more

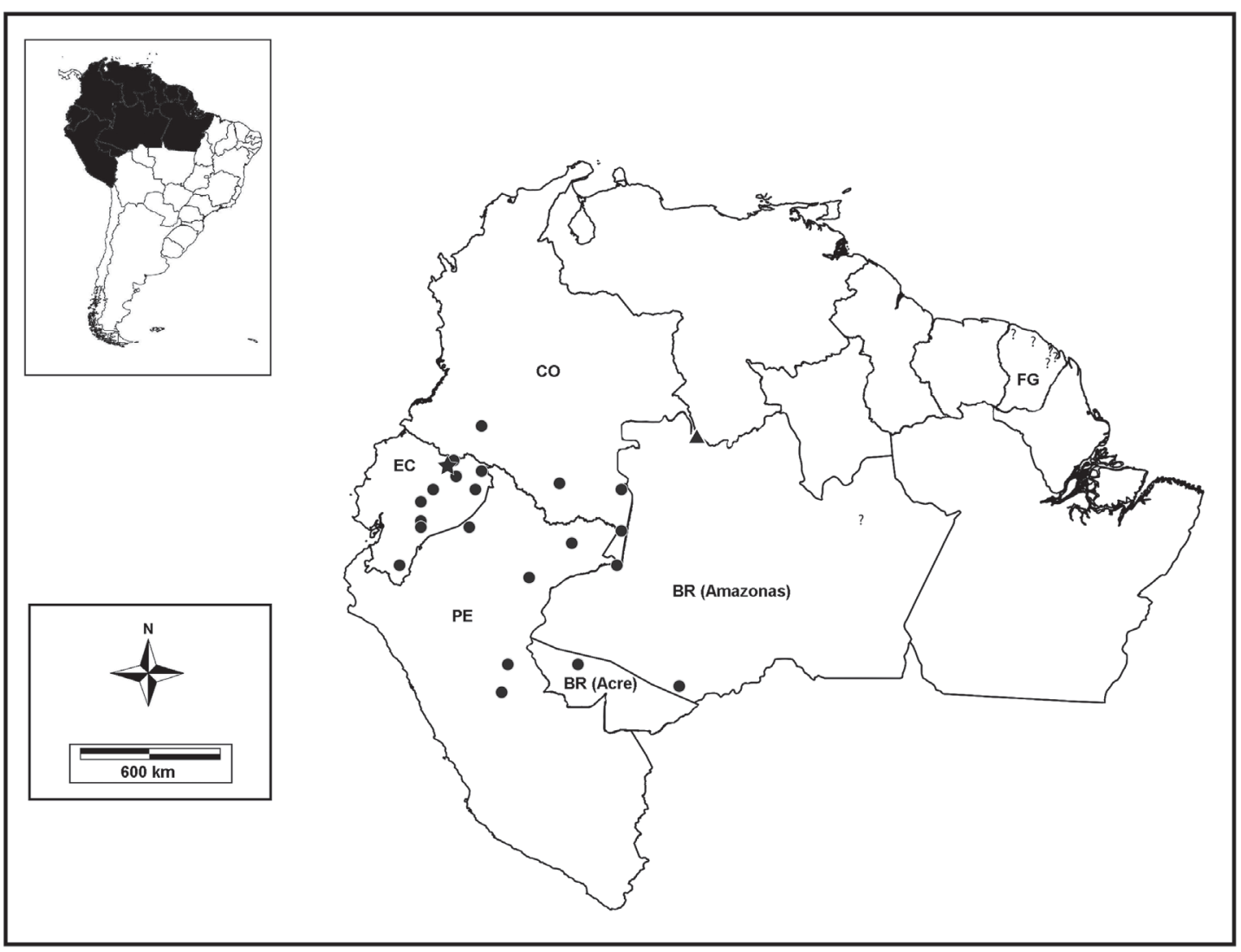

Figure 3. Known localities of occurrence of Scinax cruentommus (dots); star is type locality (Santa Cecilia, Sucumbíos, Ecuador); triangle is the new record (Cucuí, Amazonas state, Brazil); question marks are localities (Amazonas, Brazil: Zimmerman and Rodrigues,1990; French Guyana: Lescure and Marty, 2000) that need reassessment (see the text). Abbreviations: $\mathrm{BR}=$ Brazil (Brazilian states), $\mathrm{CO}=$ Colombia, $\mathrm{EC}=$ Ecuador, $\mathrm{FG}=$ French Guyana, PE = Peru. Records in Ecuador and Peru were based on Duellman and Wiens (1993); in Colombia, Malambo-L and Madrid-Ordóñez (2008); in Brazil, França and Venâncio (2010) and Bernarde et al. (2011). 
accurate sound analysis, especially in spectral traits. Acoustic data from Lescure and Marty (2000) fits neither Duellman's (1972) nor our data, especially with respect to call duration (120 $\mathrm{ms}$ ), which is approximately half of our minimum value for this call trait (216-336 ms). The remarkably shorter call provided in Lescure and Marty (2000) indicate that the records of $S$. cruentommus from French Guyana should be reassessed based on the new acoustic information available in the present study.

With the assessment of further data on Scinax cruentommus, the acoustic traits have supplemented its diagnosis in comparison with the other species of the $S$. ruber clade in the Amazon Basin. Additionally, the remarkable differences in call traits from French Guyana (Lescure and Marty 2000) and our data suggest that $S$. cruentommus may not occur in the Guianan Region and may be restricted to the upper Amazon Basin. The confirmation of the questionable record nearby Manaus (Zimmerman and Rodrigues 1990) would support that restriction.

\section{Acknowledgments}

Financial support was granted by $\mathrm{CNPq}$, FAPEMIG, and FAPESP. A research grant was conceded by CNPq to AAG. Doctoral fellowships were conceded by FAPESP to TRC and CAPES to BFVT. We are grateful to Rafael Márquez for making available recordings of $S$. cruentommus made by William E. Duellman from Fonoteca Zoológica Sound Collection, Osmar Cordeiro, his family, and his brother (Odimar Cordeiro) for the invaluable assistance and logistics in the village of Cucuí, FOIRN (Federação das Organizações Indígenas do Rio Negro) and FUNAI/SGC (Fundação Nacional do Índio/São Gabriel da Cachoeira) by the access to the indigenous communities, two anonymous reviewers for suggestions in an earlier version of this study. Collection permit was conceded by ICMBio/SISBIO (30059-5).

\section{References}

Barrio-Amorós, C. L., A. Orellana, and A. Chacón. 2004. A new species of Scinax (Anura: Hylidae) from the Andes of Venezuela. Journal of Herpetology 38: 105-112.

Bernarde, P. S., R. A. Machado, and L. C. B. Turci. 2011. Herpetofauna da área do Igarapé Esperança na Reserva Extrativista Riozinho da Liberdade, Acre, Brasil. Biota Neotropica 11: 117-144.

Bilate, M. and E. Lack. 2011. The advertisement call of Scinax similis (Cochran, 1952) (Amphibia, Anura). South American Journal of Herpetology 6: 54-58.

Bioacoustics Research Program. 2012. Raven Pro: Interactive Sound Analysis Software. Version 1.5. URL: http:// www.birds.cornell.edu/brp/raven/RavenOverview.html

Brusquetti, F., M. Jansen, C. Barrio-Amorós, M. Segalla, and C. F. B. Haddad. 2014. Taxonomic review of Scinax fuscomarginatus (Lutz, 1925) and related species (Anura; Hylidae). Zoological Journal of the Linnean Society 171: 783-821.

Duellman, W. E. (ed.). 1970. The Hylid Frogs of Middle America. Lawrence. The University of Kansas Press. 473 pp.

Duellman, W. E. 1972. A new species of Hyla from Amazonian Ecuador. Copeia 1972: 265-271.

Duellman, W. E. 1978. The biology of an equatorial herpetofauna in Amazonian Ecuador. Miscellaneous Publication, Museum of Natural History, University of Kansas 65: 1-352.

Duellman, W. E. 1986. Two new species of Ololygon (Anura: Hylidae) from the Venezuelan Guyana. Copeia 1986: 864-870.

Duellman, W. E. and R. A. Pyles. 1983. Acoustic resource partitioning in anuran communities. Copeia 1983: 639_ 649.

Duellman, W. E. and J. J. Wiens. 1993. Hylid frogs of the genus Scinax Wagler, 1830, in Amazonian Ecuador and Peru. Occasional Papers of the Museum of Natural History University of Kansas 153: 1-57.

Duellman W. E. and L. Trueb (eds.). 1994. Biology of Amphibians. Baltimore. The Johns Hopkins University Press. 670 pp.

Faivovich, J. 2002. A cladistics analysis of Scinax (Anura: Hylidae). Cladistics 18: 367-393.

Faivovich, J., C. F. B. Haddad, P. C. A. Garcia, D. R. Frost, J. A. Campbell, and W. C. Wheeler. 2005. Systematic review of the frog family Hylidae, with special reference 
to Hylinae: phylogenetic analysis and taxonomic revision. Bulletin of the American Museum Natural History 294: 1-240.

Fouquette, M. J., Jr. and W. F. Pyburn. 1972. A new Colombian treefrog of the Hyla rubra complex. Herpetologica 28: 176-181.

França, F. G. R. and N. M. Venâncio. 2010. Reptiles and amphibians of a poorly known region in southwest Amazonia. Biotemas 23: 71-84.

Frost, D. R. (ed.). 2015. Amphibian Species of the World: an Online Reference. Version 6.0. Electronic Database accessible at http://research.amnh.org/vz/herpetology/ amphibia/index.php American Museum of Natural History, New York, USA. Captured on 18 Sept. 2015.

Lescure, J. and C. Marty. 2000. Atlas des Amphibiens de Guyane. Paris. Muséum National D'Histoire Naturelle. $388 \mathrm{pp}$.

Lima, A. P., W. E. Magnusson, M. Menin, L. K. Erdtmann, D. J. Rodrigues, C. Keller, and W. Hödl (eds.). 2005. Guide to the frogs of Reserva Adolpho Ducke, Central Amazonia. Manaus. Áttema Design Editorial. 168 pp.

Lynch J. D. 2005. Discovery of the richest frog fauna in the world-an exploration of the forests to the north of
Leticia. Revista de Academia Colombiana de Ciencias 29: 581-588.

Malambo-L., C. and M. A. Madrid-Ordóñez. 2008. Geographic distribution of Limnophys sulcatus, Rhinella castaneotica and Scinax cruentommus (Amphibia: Anura) for Colombia. Revista de Academia Colombiana de Ciencias 32: 285-289.

Pyburn, W. F. 1992. A new tree frog of the genus Scinax from the Vaupés River of northwestern Brazil. Texas Journal of Science 44: 405-411.

Pyburn, W. F. and M. J. Fouquette Jr. 1971. A new striped treefrog from central Colombia. Journal of Herpetology 5: 97-101.

R Core Team. 2014. R Foundation for Statistical Computing. Version 3.1.0. URL: http://www.R-project.org (accessed on 19 March 2015).

Sueur, J., T. Aubin, and C. Simonis. 2008. Seewave, a free modular tool for sound analysis and synthesis. Bioacoustics 18: 213-226.

Zimmerman, B. L. and M. T. Rodrigues. 1990. Frogs, Snakes, and Lizards of the INPA/WWF Reserves near Manaus, Brazil. Pp. 426-454 in A. H. Gentry (ed.), Four Neotropical Rainforests. New Haven. Yale University Press.

Editor: Jaime Bertoluci 